\title{
Unusual Coloration of a Hairy Woodpecker from Oregon
}

Author(s): Steven R. Helm, Regina Stemmer, and Hein van Grouw

Source: Northwestern Naturalist, 92(1):76-78. 2011.

Published By: Society for Northwestern Vertebrate Biology

DOI: $10.1898 / 10-19.1$

URL: http://www.bioone.org/doi/full/10.1898/10-19.1

BioOne (www.bioone.org) is an electronic aggregator of bioscience research content, and the online home to over 160 journals and books published by not-for-profit societies, associations, museums, institutions, and presses.

Your use of this PDF, the BioOne Web site, and all posted and associated content indicates your acceptance of BioOne's Terms of Use, available at www.bioone.org/page/terms_of_use.

Usage of BioOne content is strictly limited to personal, educational, and non-commercial use. Commercial inquiries or rights and permissions requests should be directed to the individual publisher as copyright holder. 


\title{
UNUSUAL COLORATION OF A HAIRY WOODPECKER FROM OREGON
}

\author{
Steven R Helm, Regina Stemmer, AND Hein van GrouW
}

Key words: Coast Range, color, Hairy Woodpecker, mutation, Oregon, Picoides villosus harrisi, plumage

An unusually colored male Hairy Woodpecker (Picoides villosus) was observed on the westslope of the Coast Range in Tillamook County, Oregon, within the Siuslaw National Forest at an elevation of approximately $220 \mathrm{~m}$ on 8 May 2010, at about 15:00 PDT. The location indicates the Pacific Northwest coastal subspecies P. $v$. harrisi (Gabrielson and Jewett 1940), which is a common forest resident over much of its range (Simmons 2003). The bird flew across Mount Hebo Road within several meters of milepost 2. A generally brown appearance was obvious as it flew, prompting great interest in further observation. The Hairy Woodpecker then foraged in Red Alder (Alnus rubra) and Douglas-fir (Pseudotsuga menziesii) on the north side of the road for several minutes, during which time it was observed by 2 of the authors through 
binoculars at an angle of approximately $30^{\circ}$ from horizontal and from a distance of approximately 15-20 m against a backdrop of dense forest vegetation. Conditions were clear, fairly warm and calm, and the bird was viewed in excellent lighting from the back and side before it flew deeper into the forest. The normal plumage pattern existed, but the regions that would typically be black (wings and parts of the head, back, and tail) were entirely of a uniform, light brown color. No black coloration was evident. Plumage typically grayish appeared normal, as did the large, bright red nuchal patch diagnostic of males. The wings appeared unspotted; $P$. $v$. harrisi typically bears unspotted or lightly spotted wings (Gabrielson and Jewett 1940; Pyle 1997).

Further investigation of the area was conducted on 22 May 2010 from 07:30 to 17:15 PDT by walking Mount Hebo Road from Highway 22 at Hebo (elevation approximately $18 \mathrm{~m}$ ) to the summit of Mount Hebo (elevation approximately $945 \mathrm{~m}$ ) and back. Two normally colored Hairy Woodpeckers, a male and female also bearing wings that appeared unspotted, were seen perhaps $1 \mathrm{~km}$ apart between mileposts 4 and 5 .

Age is not thought to be responsible for the unusual coloration observed, as juveniles also have black coloration (Gabrielson and Jewett 1940; Pyle 1997). With advances in genetic techniques, plumage color mutations have drawn increased study, and at least several are possible to explain the observation. Schizochroism, meaning "split colors", is a mutation resulting from absence of a melanin pigment (for example Van Tyne and Berger 1976), but would only be possible if Hairy Woodpeckers possess both types of melanin pigments (eumelanin and phaeomelanin); whether or not they do was not revealed in our search of the literature. Schizochroism results in abnormally pale plumage that is either brown or gray for most species of birds affected (van Grouw 2006). A sex-linked recessive mutation known as "brown" (for example Carefoot 1996) results from incomplete oxidation of eumelanin and yields brown plumage instead of black, which can become paler from effects of sunlight (van Grouw 2006). Dilution is a mutation that results from a quantitative reduction of melanin pigments and yields pale plumage, which can be quite different in color from the norm (for example Vaez and others 2008). While these mutations, especially brown and dilution, appear plausible to explain the observation, there may be other genetic abnormalities that could be proposed, and perhaps there are others that are yet unknown.

The photograph in van Grouw (2006) showing brown in the Common Gull (Larus canus) provides a good likeness of the atypical color observed in the subject Hairy Woodpecker. Review of the literature revealed no accounts of this sort of substitution of color in Hairy Woodpeckers. Although some subspecies of the Hairy Woodpecker are lighter than others (for example Miller and others 1999), it appears that little color variation typically exists in black portions of the plumage (for example Jackson and others 2002). Plumage color aberrations have been reported for Hairy Woodpeckers: an apparently melanic individual was collected in New Mexico (Short 1969), and LaFrance (1983) reported an individual from New York where typically white plumage was replaced by brown. With respect to mutations postulated to explain the observation and for woodpeckers in general, schizochroism was reported in the Black Woodpecker (Dryocopus martius) of the Old World (Jackson 1999), while no accounts of brown or dilution were revealed in the literature. Assignment of mutations based only on gross phenotypic observations, however, can be speculative and, in some cases, plumage color mutations reported in the early literature are incorrect by modern definitions as shown through genetic studies. For example, it was thought that incompletely oxidized eumelanin was a separate pigment, which could have led to brown being misdiagnosed as schizochroism. A detailed review of the chemistry and physics of melanin-based coloration is provided in McGraw (2006).

It is interesting that the "brown-backed" species of Picoides, the Strickland's (P. stricklandi) and Arizona (P. arizonae) Woodpeckers (formerly considered conspecific), are close relatives of the Hairy Woodpecker (Davis 1965; Johnson and others 1999) and are thought to have diverged from ancestral Hairy Woodpecker stock as late as the Pleistocene (Winkler 1979). Pleistocene glacial advance and retreat has been proposed as an important isolating mechanism in speciation within Picoides in 
general in western North America (Jackson and others 2002). While a pine-dominated arboreal center in Mexico may have provided refugia for speciation (Winkler 1979), no speculation was revealed in the literature regarding specific causal agents of divergence from Hairy Woodpecker stock. Reproductive isolation within populations, however, is often initiated by recognition failure of potential mates (for example Baker and Baker 1990; Shaw and Parsons 2002). Research on Monarcha flycatchers in the Solomon Islands (Uy and others 2009) suggests that establishment and retention of atypical plumage coloration, caused in this case by a single amino acid substitution that yields black ventral coloration instead of the typical chestnut, can contribute to speciation via social selection. Given this result, it is plausible to consider that the coloration of the subject Hairy Woodpecker could be abnormal enough to cause recognition failure. It is hoped that additional field time in the Mount Hebo area will yield further observations.

Acknowledgments.-We thank RL Hoffman and an anonymous referee for their reviews and comments, which improved the manuscript.

\section{LITERATURE CITED}

BAKER MC, BAKER AEM. 1990. Reproductive behavior of female buntings: Isolating mechanisms in a hybridizing pair of species. Evolution 44:332-338.

CAREFOOT WC. 1996. Chocolate: A sex-linked recessive plumage colour mutant of the domestic fowl. British Poultry Science 37:867-868.

DAVIS J. 1965. Natural history, variation, and distribution of the Strickland's Woodpecker. Auk 82: 537-590.

GABRIELSON IN, JEWETT SG. 1940. Birds of Oregon. Corvallis, OR: Oregon State College. Oregon State Monographs, Studies in Zoology, Number 2. 650 p.

JACKSON JA. 1999. Color deviations in the Black Woodpecker (Dryocopus martius). Journal of Field Ornithology 70:291-292.

JACKSON JA, OUELLET HR, JACKSON BJS. 2002. Hairy Woodpecker (Picoides villosus). In: Poole A, Stellenheim P, Gill F, editors. The birds of North America, Number 702. Philadelphia, PA: Academy of Natural Sciences of Philadelphia; Washington DC: American Ornithologists' Union. 32 p.

JOHNSON RR, HAIGHT LT, LiGON JD. 1999. Strickland's Woodpecker (Picoides stricklandi). In: Poole A, Stellenheim P, Gill F, editors. The birds of North
America, Number 474. Philadelphia, PA: Academy of Natural Sciences of Philadelphia; Washington DC: American Ornithologists' Union. 15 p.

LAFRANCE F. 1983. Adirondack woodpeckers in unusual plumages. Kingbird 33:165-166.

MCGRAW KJ. 2006. Mechanics of melanin-based coloration. In: Hill GE, McGraw KJ, editors. Bird Coloration, Volume 1 (Mechanics and measurements). Cambridge, MA: Harvard University Press. p 243-294.

Miller EH, Walters EL, Ouellet H. 1999. Plumage, size, and sexual dimorphism in the Queen Charlotte Islands Hairy Woodpecker. Condor 101:86-95.

PYLE P. 1997. Identification guide to North American birds, Part 1 (Columbidae to Ploceidae). Bolinas, CA: Salt Creek Press. 732 p.

SHAW KL, PARSONS YM. 2002. Divergence of mate recognition behavior and its consequences for genetic architectures of speciation. American Naturalist 159:S61-S75.

SHORT LL. 1969. An apparently melanic Hairy Woodpecker from New Mexico. Bird-Banding 40:145-146.

SIMMONS J. 2003. Hairy Woodpecker (Picoides villosus). In: Marshall DB, Hunter MG, Contreras AL, editors. Birds of Oregon: A general reference. Corvallis, OR: Oregon State University Press. p 362-364.

Uy JAC, Moyle RG, Filardi CE, Cheviron ZA. 2009. Difference in plumage color used in species recognition between incipient species is linked to a single amino acid substitution in the melanocortin-1 receptor. American Naturalist 174:244-254.

VAeZ M, FOLletT SA, BED'HOM B, GOURICHON D, TIXIER-BOICHARD M, BURKE T. 2008. A single pointmutation within the melanophilin gene causes the lavender plumage colour dilution phenotype in the chicken. BMC Genetics 9:7 (9 p.).

VAN GROUW H. 2006. Not every white bird is an albino: Sense and nonsense about colour aberrations in birds. Dutch Birding 28:78-89.

VAN TYNE J, BERGER AJ. 1976. Fundamentals of ornithology, 2nd ed. New York, NY: John Wiley and Sons. 808 p.

WINKLER H. 1979. Foraging ecology of Strickland's Woodpecker in Arizona. Wilson Bulletin 91:244-254.

US Army Corps of Engineers, PO Box 2946 (CENWP-PM-E), Portland, OR 97208; steve.r.helm@ usace.army.mil (SRH); 625 SW 9th Street, \#27, Dundee, OR 97115 (RS); Bird Group, Department of Zoology, The Natural History Museum, Akeman Street, Tring, Herts, HP23 6AP, UK; h.van-grouw@ nhm.ac.uk (HvG). Submitted 26 May 2010, accepted 27 September 2010. Corresponding Editor: Joan Hagar. 